\title{
Rancang Bangun Pencuci Tangan Berbasis Water Level Control di Pesantren Darul Muttaqin Kabupaten Sinjai
}

\author{
Rani Bastari Alkam¹, Suriati Abd. Muin² \\ rani.bastari@umi.ac.id ${ }^{1}$, suriati.abdmuin@umi.ac.id² \\ 1,2Universitas Muslim Indonesia
}

\begin{abstract}
Article History:
Received: 05-01-2022

Revised: 13-01-2022

Accepted: $18-01-2022$
\end{abstract}

Keywords: hand washer, water level control, Islamic boarding school, Covid-19

\begin{abstract}
Washing hands using soap is one of the three main movements of an effective health protocol to mitigate the transmission of Covid-19 and other infectious diseases. To apply this protocol, Darul Muttaqin Islamic Boarding School as a partner of this activity lacks of physical infrastructure to support and encourage the habit of washing hands in the community. This program is directed at procuring hand washing equipment with a water level control and an integrated disposal system at the site. The form and stages of the program are formulated based on intensive discussions with the partners. The hand washing equipment has been produced in the design and the manufacturing stage. The design stages include the model design, the dimension determinations, and the budget plan calculation. While the manufacturing stages include the manufacture of the structure, installation of reservoirs and accessories, electrical installations, and installation of drainage and sewer lines. The dual-function hand washing device is an output product of this program which has been handed over to partners to be used as best as possible by the students.
\end{abstract}

\section{Pendahuluan}

Lembaga pendidikan pesantren pada umumnya diselenggarakan dalam bentuk asrama sebagai suatu komunitas tersendiri di bawah pimpinan ulama yang dibantu oleh beberapa ustadz dan ustadzah sebagai tenaga pengajar, dengan Masjid atau Surau sebagai pusat kegiatan peribadatan keagamaan (Syafe'i, 2017). Konsep ini juga diterapkan pada pondok pesantren Darul Muttaqin yang berlokasi di ibukota kecamatan Tellulimpoe kabupaten Sinjai Sulawesi Selatan dengan jarak sejauh 0-1 Km dari pusat kelurahan dan sejauh 1-2 Km dari pusat kecamatan dimana berdasarkan pantauan dalam observasi awal, pesantren ini didukung infrastruktur bangunan pada tiga lokasi terpisah dengan jarak berdekatan yaitu: 1) lokasi utama terdiri dari gedung belajar, masjid, ruang kantor, asrama putra; 2) kediaman pembina, asrama putra dan putri; 3) asrama Putri, perpustakaan mini, dan ruang komputer.

Selama 24 jam, prasarana pesantren menjadi basis kehidupan kolektif antara kyai, ustadz, santri dan para pengasuh pesantren lainnya, sebagai satu keluarga besar (Hayati, 2011). Prasarana utama yang terdiri dari gedung sekolah atau ruang belajar sangat vital sebagai pusat kegiatan belajar mengajar, sedangkan pondok menjadi tempat tinggal santri untuk istirahat dan menjalankan kegiatan esensial lainnya dalam keseharian. Dari hasil 
pengamatan langsung di lapangan yang didukung oleh keluhan para pengelola, sarana dan prasarana di Pesantren Darul Muttaqin masih sangat minim terutama pada fasilitas belajar dan pondokan yang masih sederhana. Ketiadaan pembayaran santri menjadikan sumber pengadaan fasilitas mengandalkan bantuan pemerintah daerah maupun pusat dan sumbangan dari alumni maupun donatur lainnya.

Salah satu yang menjadi perhatian utama adalah ketersediaan air bersih untuk wudhu dan cuci tangan utamanya dalam masa pandemi Covid-19. Di pesantren ini, terdapat dua sumber air yaitu PDAM dan sumur. Salah seorang pengelola mengatakan bahwa pasokan air dari PDAM seringkali tidak mengalir sehingga para santri harus menimba dari sumur untuk keperluan wudhu dan mandi. Selain itu, terdapat jarak sekitar 13 meter antara toilet dan masjid serta belum disediakan wastafel pencuci tangan bagi para santri di lokasi utama pesantren. Ketiadaan fasilitas ini menjadikan para santri menjadi tidak terbiasa dalam menerapkan protokol kesehatan di lingkungan pesantren.

Pondok pesantren Darul Muttaqin kelurahan Mannanti merupakan pondok pesantren salafiyah (Mujizatullah, 2019). Beberapa hasil penelitian menunjukkan budaya hidup di pondok pesantren salafi tidak memenuhi pola hidup sehat dimana sosialisasi sanitasi diri dan lingkungan perlu ditanamkan kepada santri untuk menjaga kesehatan dan kebersihan lingkungan sekitar (Wahyudin \& Arifin, 2015). Selain minimnya pemahaman akan risiko covid19, ketersediaan sarana dan prasarana pendukung juga berpengaruh terhadap perilaku hidup sehat para santri utamanya di masa pandemi. Salah satu faktor yang mempengaruhi kualitas perilaku kesehatan santri adalah fasilitas pondok dimana keterbatasan sarana sanitasi dan perilaku santri yang belum menganut Perilaku Hidup Bersih dan Sehat (PHBS) sangat berkaitan dengan angka kesakitan berbasis lingkungan yang menular (Nasihah et al., 2019).

Terdapat keterbatasan jumlah wastafel pencuci tangan yang dapat ditemukan di depan pondok maupun ruang kelas di pondok pesantren Darul Muttaqin. Dari yang dapat diidentifikasi, hanya terdapat satu wastafel yang diletakkan di tengah depan gedung kelas dimana alat pencuci tangan tersbut tidak dilengkapi dengan sabun pencuci tangan. Hal ini tidak sejalan dengan syarat penyelenggaraan pembelajaran tatap muka di lingkungan pesantren poin kedua yaitu memiliki fasilitas yang memenuhi protokol kesehatan.

Selain itu, Kementerian Agama telah menerbitkan protokol santri saat kembali ke pondok pesantren dan selama berada di pesantren sebagai antisipasi penyebaran Covid-19, salah satunya yaitu rajin mencuci tangan dengan sabun/hand sanitizer (Basid \& Saimroh, 2020). Identiknya pesantren akan kehidupan yang sederhana dan sarana dan prasarana yang terbatas, berdampak pada keterbatasan pengetahuan tentang kesehatan dan perilaku mencuci tangan yang masih belum menjadi kebiasaan padahal mencuci tangan menggunakan sabun merupakan upaya preventif dalam melindungi diri dari berbagai penyakit menular (Purnama et al., 2020). Kurangnya alat pencuci tangan yang disediakan di pesantren 
Darul Muttaqin merupakan masalah yang penting untuk segera diselesaikan dalam masa pandemi covid-19 ini.

Permasalahan lain yang ditemukan adalah keterbatasan penampungan air yang tersedia pada pondok pesantren Darul Muttaqin sehingga jika aliran air PDAM mati, para santri harus menimba air di sumur untuk keperluan mandi maupun wudhu, padahal terdapat jarak belasan meter antara Masjid dan sumur ataupun toilet. Karena itu, ketersediaan penampungan air di pesantren merupakan kebutuhan mendesak untuk mengantisipasi kekurangan air bersih. Dari pantauan penulis di lokasi, hanya terdapat satu bak penampungan air yang diletakkan antara masjid dan ruang kelas yang saat ini dialihfungsikan sebagai asrama pria untuk sementara waktu.

\section{Metode}

Berdasarkan prioritas permasalahan yang dialami oleh mitra yaitu kurangnya prasarana penunjang penerapan protokol kesehatan yaitu alat pencuci tangan, maka secara umum kegiatan ini diarahkan untuk pengadaan alat pencuci tangan berbasis water level control dengan sistem pembuangan yang terintegrasi di lokasi pesantren. Hasil penelitian menunjukkan ketersediaan sarana dan prasarana yang lengkap mampu mendorong santri untuk berperilaku menjaga kebersihan diri yang baik sebanyak 10.335 kali lebih besar dibandingkan dengan santri yang ketersediaan sarana dan prasarananya kurang lengkap (Zakiudin \& Shaluhiyah, 2016). Karena itu, salah satu langkah awal dalam menggalakkan penerapan adaptasi kebiasaan baru di pondok pesantren ini adalah penyediaan alat pencuci tangan.

Mencuci tangan dengan sabun anti mikroba atau pembersih berbasis alkohol merupakan langkah efektif dalam mencegah penularan penyakit mikroba (Gupta \& Lipner, 2020). Produk berbasis alkohol, yang mencakup hampir semua produk "disinfektan", mampu membunuh virus dengan cara yang sama tetapi mencuci tangan dengan sabun lebih baik karena hanya membutuhkan sedikit air sabun, yang dengan menggosok, menutupi seluruh tangan dengan mudah (Nakoe et al., 2020). Karena itu alat pencuci tangan yang ditargetkan untuk diadakan di pesantren dilengkapi dengan sabun pencuci tangan.

Selain itu, permasalahan kekurangan bak penampungan air bersih di pesantren mengarahkan tim untuk tidak hanya menyediakan alat pencuci tangan dengan fungsi tunggal, tetapi juga diharapkan mampu menjadi prasarana dwi fungsi yaitu untuk cuci tangan dan berwudhu. Berikut adalah gambar rancangan alat pencuci tangan yang telah diadakan di lokasi pelaksanaan program. 


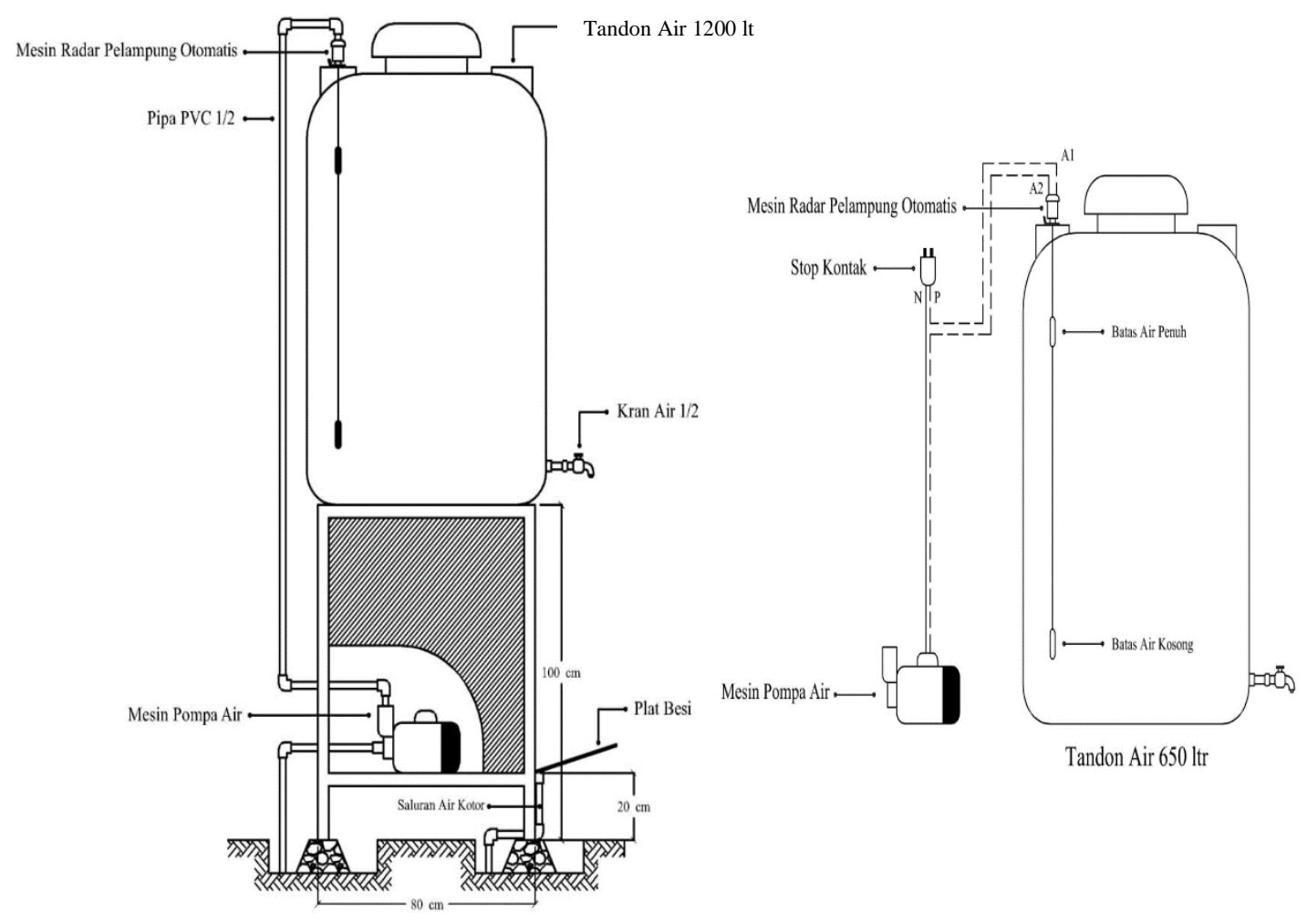

Gambar 1. Gambar rancangan alat pencuci tangan dan water level control

Untuk memudahkan pengelola dan santri dalam pemanfaatan dan pemeliharaan alat pencuci tangan ini maka sistem pengaliran air dari sumber air ke bak penampungan dibuat berbasis water level control. Tandon yang dilengkapi dengan water level control mengatur proses pengisian air pada tandon, agar proses pengisian air menjadi lebih efektif karena tidak perlu dikendalikan dan dimonitor secara manual untuk mematikan atau menghidupkan mesin pompa air secara berkala (Hayusman et al., 2020). Ketika sistem water level control ini diaktifkan, pemilik tidak perlu menunggu apakah tangki air sudah penuh atau belum dengan demikian dapat menghemat air, listrik, dan waktu, karena tidak ada air dan listrik yang terbuang sia-sia, karena lupa mematikan pompa air (Aviv et al., 2016).

Selain mempertimbangkan sistem pengaliran yang efektif, tim juga memikirkan mengenai desain sistem pembuangan yang terintegrasi agar mampu mewujudkan alat pencuci tangan ramah lingkungan yang mengedepankan estetika dan sejalan dengan konsep adiwiyata. Agar air buangan cuci tangan tidak merembes dan mengotori lingkungan sekitar, besi plat ditempatkan di sisi dudukan tandon lalu dibuat talang air yang juga berbahan besi plat yang mengitari dudukan untuk menghimpun air buangan keran dan menyalurkannya ke satu pipa pembuangan yang dialirkan ke saluran drainase terdekat.

Untuk dapat mencapai solusi dan luaran yang ditargetkan menurut permasalahan mitra, maka dilakukan program kemitraan masyarakat secara terprogram mengikuti tahapan https://journal.universitasbumigora.ac.id/index.php/ADMA 
sebagai berikut:

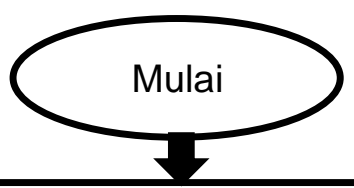

\section{Interaksi dengan Mitra}

Menggali permasalahan spesifik yang dihadapi mitra dan merumuskan solusi yang tepat sesuai dengan pengetahuan dan kapabilitas tim.

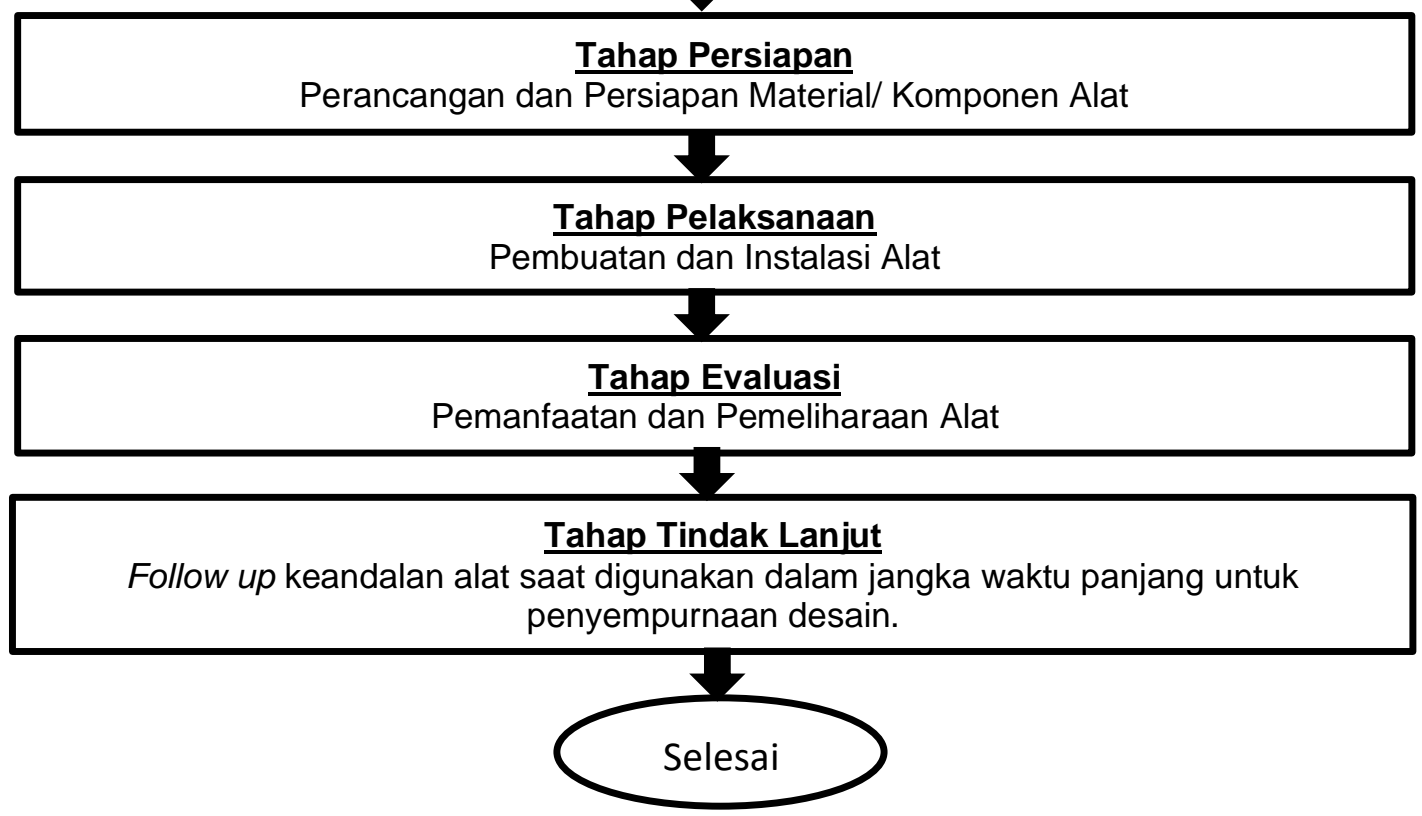

Gambar 2. Diagram alir pelaksanaan program kemitraan masyarakat

Adapun langkah-langkah yang ditempuh sebelum dan selama pelaksanaan kegiatan adalah:

1) Perancangan

Tahapan perancangan meliputi aspek model, dimensi, dan anggaran. Penggambaran model alat dilakukan dengan mempertimbangkan segala permasalahan pada mitra sehingga dapat diakomodir dalam satu alat yang fungsional. Rencana desain alat dapat dilihat pada Gambar 1. Dimensi alat dirancang menyesuaikan dengan tinggi badan rata-rata para santri. Adapun untuk rencana anggaran biaya pembuatan alat disesuaikan dengan ketersediaan anggaran kegiatan, model, dan dimensi alat.

2) Persiapan material/ komponen alat

Setelah alat didesain sesuai kebutuhan dan kesepakatan dengan mitra, selanjutnya dilakukan pendataan komponen/ material untuk selanjutnya dilakukan pembelian alat dengan merk dan dimensi setiap item yang menyesuaikan estimasi harga dan alokasi biaya pada rencana anggaran biaya.

3) Pembuatan alat pencuci tangan 
Proses pembuatan alat terdiri dari:

a) Pembuatan dudukan besi beserta kelengkapan besi plat untuk penadahan air buangan. Dudukan besi terdiri dari besi siku yang diukur, dipotong, dan di las mengikuti model rancangan. Dudukan tersebut kemudian ditutupi dengan besi pelat di ke empat sisinya serta pembuatan talang air dari besi pelat di bagian bawah alat untuk selanjutnya dialirkan ke saluran pembuangan.

b) Instalasi toren air dan bagian pelengkap. Toren air yang digunakan memiliki kapasitas 1200 L. Liquid Level Control Switch dan kabel radar dipasang di permukaan atas toren sebagai instrumen konsep water level control. Selain itu, pada toren tersebut dipasang keran air pada ke empat sisi serta dilengkapi dengan tempat sabun tangan, tissue untuk mengelap tangan, dan stiker panduan cara mencuci tangan.

c) Instalasi mesin dan sambungan listrik. Berdasarkan diskusi dengan mitra, rumah pembina yang terletak di dekat sumur di lokasi utama pesantren dapat menjadi sumber listrik dalam penggunaan mesin air seperti keperluan penggunaan listrik lainnya. Karena itu dibutuhkan kabel listrik, isolasi listrik, dan stekker dalam pemasangan mesin air.

d) Instalasi pipa untuk pengaliran air dan saluran pembuangan. Berdasarkan diskusi awal dengan mitra, terdapat dua alternatif sumber air yang dapat digunakan yaitu dari sumur atau dari air ledeng PDAM. Pada hari pelaksanaan program, diputuskan untuk menggunakan sumber air dari sumur. Untuk menghubungkan sumber air dengan teron dilakukan instalasi pipa dengan mengukur jarak dari sumber air ke titik perletakan teron. Selain itu juga dibutuhkan saluran pembuangan terintegrasi dari teron ke saluran drainase.

Keseluruhan tahap pembuatan ini dilakukan dengan pendekatan partisipatif dan kolaboratif agar para santri dan pengelola memahami prinsip kerja alat serta konsep IPTEK yang diterapkan pada alat.

4) Pemanfaatan dan pemeliharaan alat

Alat yang telah jadi selanjutnya diserahterimakan kepada pengelola yang selanjutnya menjadi fasilitas di pesantren untuk dipergunakan sesuai fungsi alat. Keberlanjutan pengoperasian dan pemeliharaan alat sangat bergantung pada rasa tanggung jawab para pengguna yaitu santri dan pengelola pesantren untuk menjaga ketahanan fisik dan fungsi dengan melakukan pemeliharaan rutin dan penggunaan yang sewajarnya. Edukasi pentingnya bercuci tangan juga harus senantiasa digalakkan oleh para pengelola pesantren 
ADMA

Jurnal Pengabdian dan Pemberdayaan Masyarakat
2022, Vol.2, No.2, pp.187-198

Doi: 10.30812/adma.v2i2.1662

agar para santri rajin mencuci tangan dengan alat yang tersedia.

\section{Pembahasan}

Kegiatan pengabdian ini diikuti oleh santri yang berjumlah 40 orang santri dari berbagai tingkat dan 12 pengajar dan pembina pesantren. Seluruh peserta yang hadir dalam kegiatan ini memperoleh informasi mengenai rencana pelaksanaan program dari pembina pesantren.

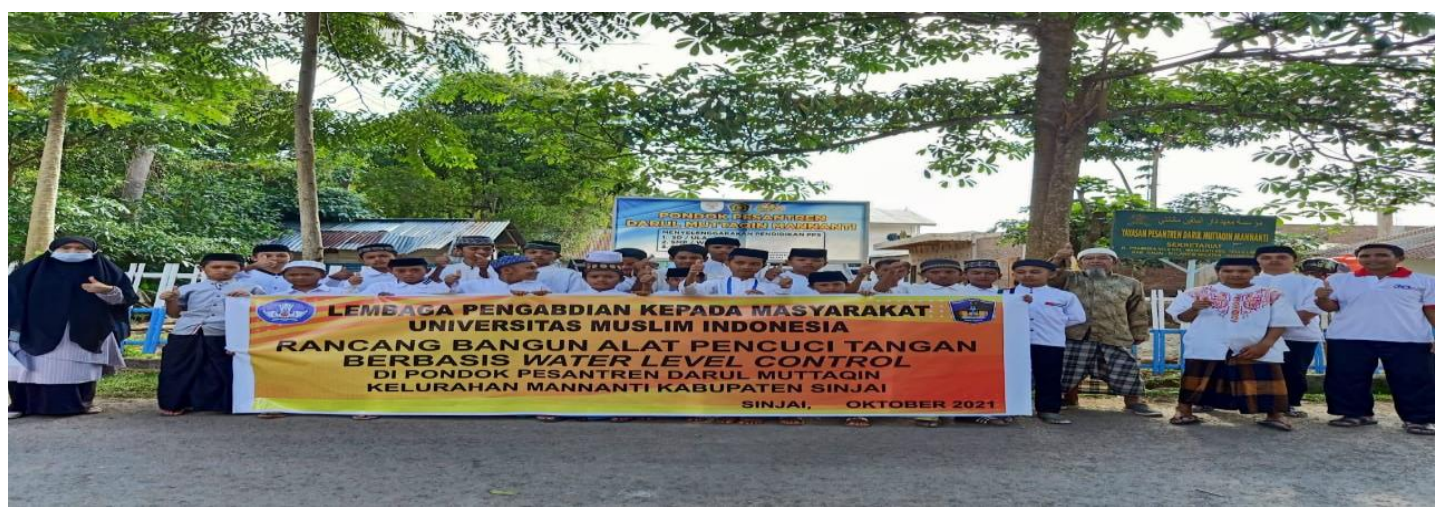

Gambar 3. Para santriwan dan pembina pondok pesantren Darul Muttaqin sebagai peserta program kemitraan masayarakat

Pada saat pelaksaanan kegiatan, anggota tim pelaksana mendampingi santriwan dan santriwati secara terpisah dimana santriwati tidak menyaksikan proses pemasangan alat, mengingat peraturan pesantren yang membatasi interaksi antara santriwan dan santriwati. Berkaitan dengan itu, setelah alat selesai dipasang, anggota tim pelaksana dan tim teknis mengunjungi pondok para santriwati yang lokasinya tidak jauh dari lokasi pemasangan alat untuk mensosialisasikan keberadaan alat, fungsi dan cara mengoperasikannya. Para santriwati termasuk masyarakat sasar dalam kegiatan ini mengingat lokasi pengadaan alat pencuci tangan adalah di dekat ruang kelas yang juga dapat diakses oleh para santriwati saat proses belajar mengajar.

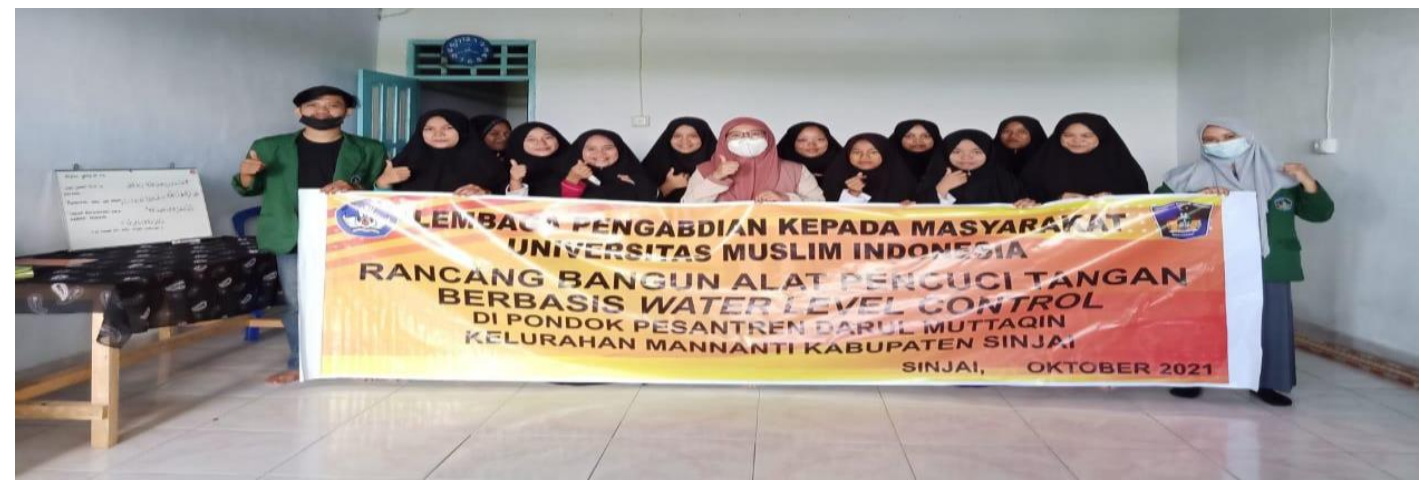

Gambar 4. Anggota tim pelaksana dan tim teknis beserta para santriwati pondok pesantren Darul Muttaqin sebagai peserta program kemitraan masayarakat

Secara keseluruhan, para peserta sangat antusias mengikuti kegiatan ini tercermin https://journal.universitasbumigora.ac.id/index.php/ADMA 
ADMA

Gurnal Pengabdian dan Pemberdayaan Masyarakat
2022, Vol.2, No.2, pp.187-198

Doi: 10.30812/adma.v2i2.1662

dari ketepatan waktu dan kekompakan peserta menghadiri kegiatan. Para santri juga terlihat sangat senang dengan keberadaan alat tersebut mengingat fungsi alat yang dapat meminimalisir kesulitan untuk memperoleh air bersih yang selama ini dihadapi para santri. Kelancaran pelaksanaan program tidak luput dari kemudahan proses mobilisasi peserta mengingat tempat jarak pondokan peserta yang tidak jauh dari tempat pelaksanaan kegiatan. Selain itu arahan dari pembina kepada para santri termasuk dalam penggunaan kostum yang seragam di hari pelaksanaan program sangat membantu terlaksananya program ini.

Berikut ini adalah gambaran alat yang telah berhasil terpasang dan sudah bisa digunakan oleh para santri.

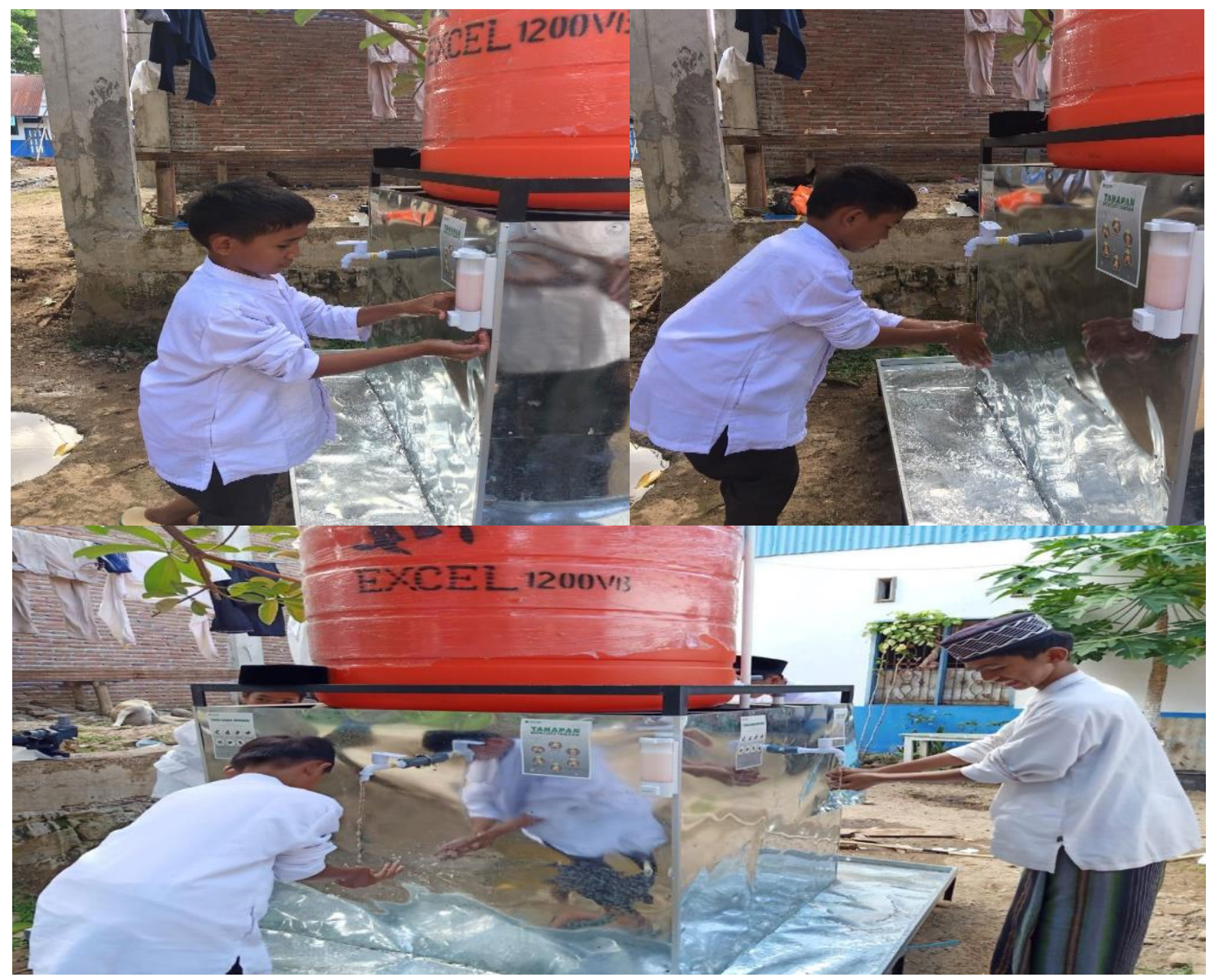

Gambar 5. Para santri menggunakan alat untuk mencuci tangan dan berwudhu

Pada Gambar 5 ditunjukkan tampilan alat yang telah dipasang dan dihubungkan dengan sistem pengaliran air di pesantern. Pada ke empat sisi alat terdapat keran air sehingga alat dapat digunakan oleh 4 orang dalam waktu bersamaan. Selain itu pada tiap sisi alat ditempelkan stiker dengan detail sebagai berikut. 


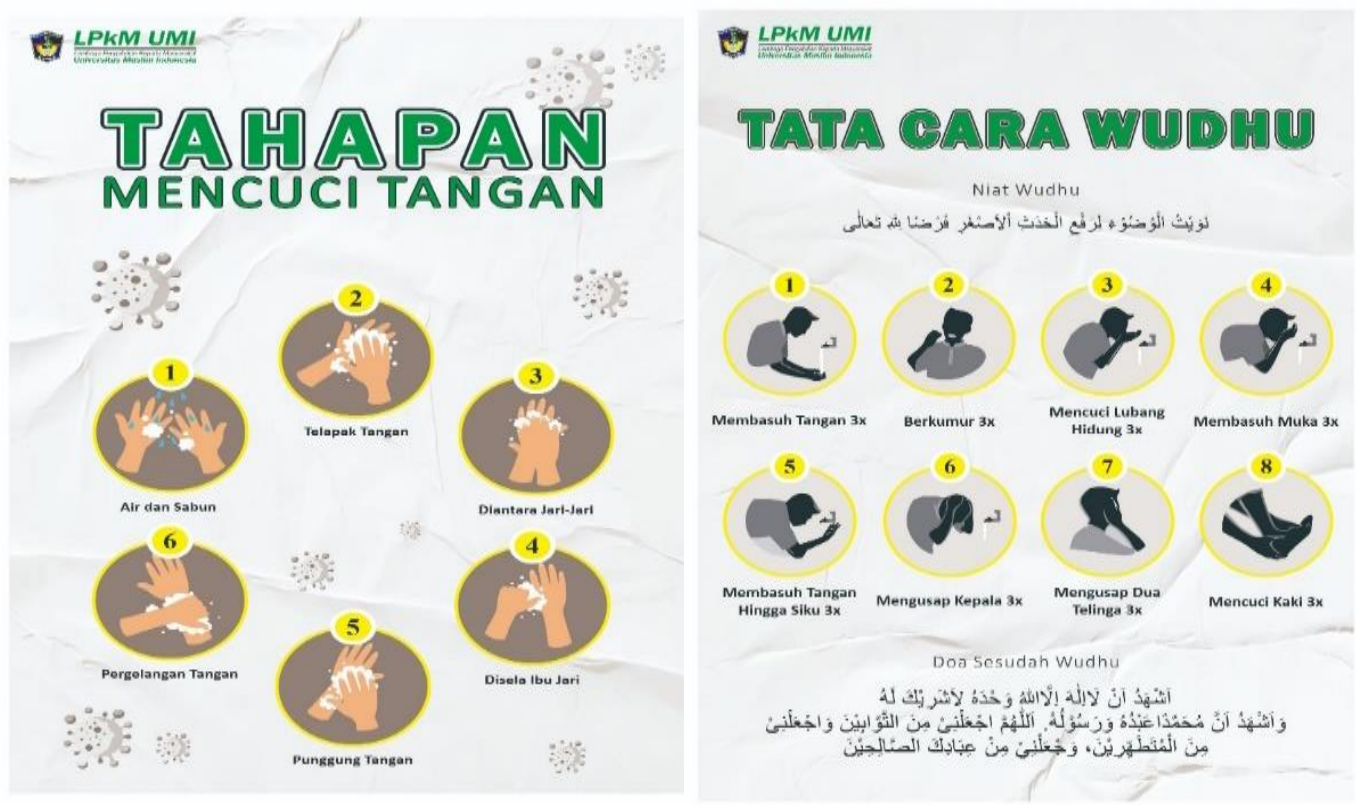

Gambar 6. Stiker panduan tahapan mencuci tangan dan tata cara wudhu

Diharapkan dengan adanya stiker yang terpasang pada alat dapat memberikan edukasi kepada para santri mengenai tata cara mencuci tangan yang benar dan kebiasaan tersebut dapat terhabituasi di kalangan pesantren untuk menjadi tindakan antisipatif pencegahan penularan penyakit tidak hanya Covid-19 tetapi berbagai penyakit menular lainnya. Selain itu pada stiker tata cara wudhu dimasukkan niat dan doa setelah wudhu untuk mengingatkan para santri untuk selalu memulai dan mengakhiri wudhu dengan doa. Misi ini sejalan dengan identitas kampus Universitas Muslim Indonesia sebagai lembaga dakwah.

Secara keseluruhan, pelaksanaan kegiatan ini berjalan dengan baik dan mitra mengapresiasi bahwa program pendampingan ini sangat bermanfaat dalam menumbuhkan pola hidup bersih dan sehat di lingkungan pesantren.

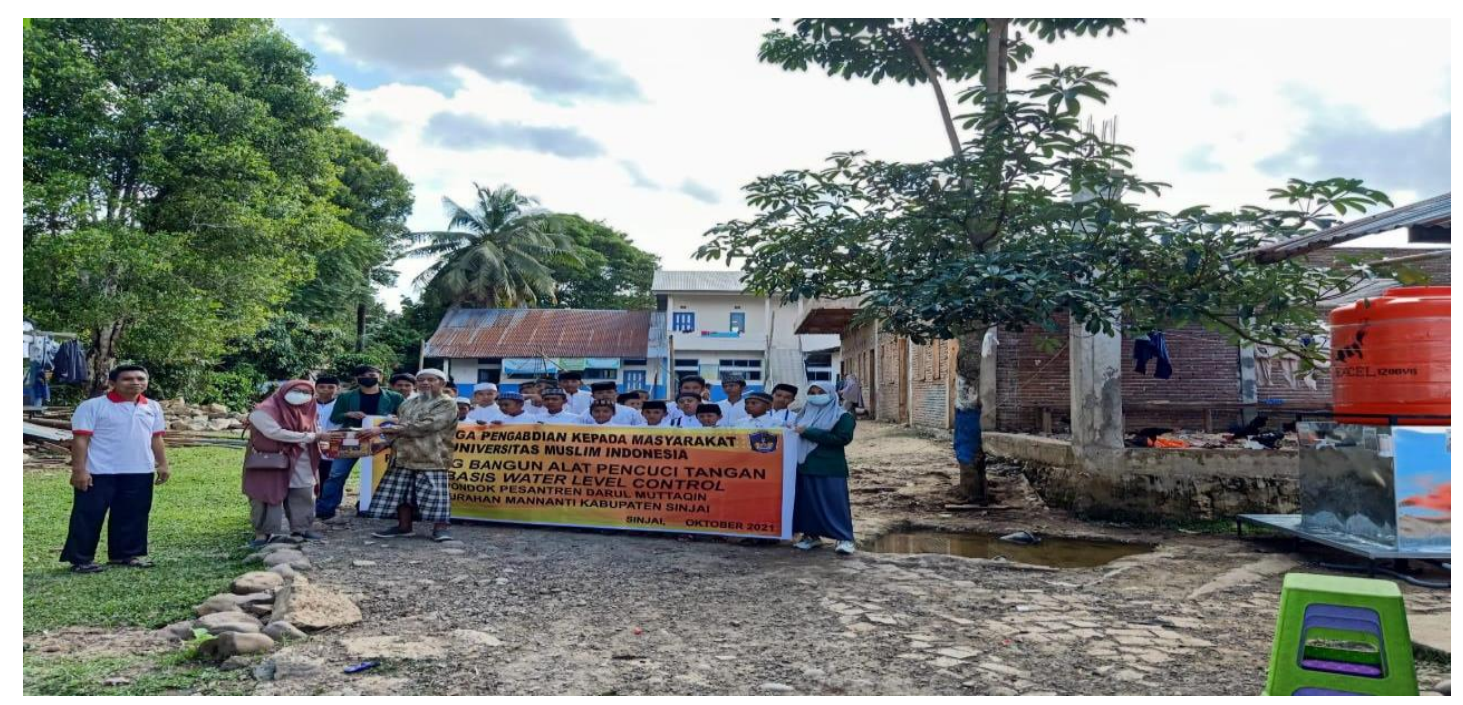

Gambar 7. Simbolis penyerahan komponen alat pencuci tangan 
Di sisi lain, peserta yakni pengajar di pondok pesantren memberikan saran dan masukan mengenai pelaksanaan kegiatan ini yaitu pelaksanaan program berikutnya diperlukan dengan tujuan untuk mengadakan prasarana kebutuhan santri lainnya misalnya sumur bor atau taman hafiz. Selain itu, pondok pesantren ini memiliki sumber daya yang terbatas utamanya untuk ketersediaan AI-Quran.

Berdasarkan evaluasi pelaksanaan dan hasil kegiatan dapat diidentifikasi permasalahan dan hambatan dalam melaksanakan program PKM Internal pemula ini yaitu sebagai berikut:

1) Keterbatasan sumber daya dan peralatan di lokasi mitra menyebabkan proses perakitan alat yang semula direncanakan dilakukan di lokasi menjadi dialihkan ke tempat lain atas persetujuan mitra.

2) Jarak universitas ke lokasi sejauh $202 \mathrm{~km}$, menjadi hambatan bagi tim untuk secara intens mengunjungi mitra dalam persiapan kegiatan. Hingga program selesai, tim yang diwakili oleh ketua tim hanya mengunjungi mitra sebanyak 4 kali. Namun intensitas tersebut dipandang cukup karena proses perakitan alat yang bisa tetap dikontrol di tempat yang berbeda.

3) Adanya proses pembangunan gedung menyebabkan perletakan alat pencuci tangan masih bersifat sementara, dimana untuk selanjutnya jika proses pembangunan selesai, mitra akan memindahkan ke tempat yang lebih pas sesuai dengan perencanaan awal.

\section{Kesimpulan}

Perancangan, perakitan, dan pemasangan alat pencuci tangan berbasis water level control dapat berjalan dengan baik dan lancar sesuai dengan konsep dan ide yang direncanakan oleh tim pengabdian. Alat ini dapat dimanfaatkan para santri dan pengelola pesantrens selain untuk mencuci tangan juga untuk berwudhu. Dudukan besi dan pelat yang dipasang disekeliling dudukan mampu mewujudkan konsep alat pencuci tangan dengan pembuangan yang terintegrasi.

\section{Ucapan Terimakasih}

Terima kasih tim sampaikan kepada Rektor Universitas Muslim Indonesia, Pimpinan beserta seluruh jajaran Lembaga Pengabdian kepada Masyarakat (LPkM) Universitas Muslim Indonesia, Dekan Fakultas Teknik Universitas Muslim Indonesia, Ketua Program Studi Teknik Sipil Universitas Muslim Indonesia, Pimpinan, pengajar, dan para santri Pondok Pesantren Darul Muttaqin serta anggota pelaksana program. 


\section{Daftar Pustaka}

Aviv, A. S., Wardayanti, A., Budiningsih, E., Fimani, A. K., \& Suhardi, B. (2016). Water Level Control Sistem Otomatis Sederhana pada Tandon Air di Kawasan Perumahan. PERFORMA: Media IImiah Teknik Industri, 15(2), 130-136. https://doi.org/10.20961/performa.15.2.9864

Basid, A., \& Saimroh. (2020). Kesiapan Pesantren Di Era Kenormalan Baru. In Pembelajaran Jarak Jauh Era Covid-19 (pp. vii-160).

Gupta, M. K., \& Lipner, S. R. (2020). Hand hygiene in preventing COVID-19 transmission. Cutis, 105(5).

Hayati, F. (2011). Pesantren: Suatu Alternatif Model Lembaga Pendidikan Kader Bangsa. MIMBAR, Jurnal Sosial Dan Pembangunan, XXVII(2), 157-163. https://media.neliti.com/media/publications/7420-ID-pesantren-suatu-alternatif-model-lembagapendidikan-kader-bangsa.pdf

Hayusman, L. M., Ali Watoni, M., Robinson, E., \& Saputra, R. R. (2020). Penerapan Water Level Control Tipe Radar dan Omron 61F-G-AP Untuk Proses Pengisian Air Bersih di Komplek Perintis Kota Banjarbaru. Jurnal Aplikasi Dan Inovasi Ipteks "Soliditas" (J-SOLID), 3(2), 62-69. https://doi.org/10.31328/js.v3i2.1591

Mujizatullah. (2019). Metode Pengajian Kitab pada Pondok Pesantren Salafiyah Darul Muttaqin Mannanti Kabupaten Sinjai. Muróbbî: Jurnal Ilmu Pendidikan, 3(2), 157-174.

Nakoe, R., S Lalu, N. A., \& Mohamad, Y. A. (2020). Perbedaan Efektivitas Hand-Sanitizer Dengan Cuci Tangan Menggunakan Sabun Sebagai Bentuk Pencegahan Covid-19. Jambura Journal of Health Sciences and Research, 2(2), 65-70. https://doi.org/10.35971/jjhsr.v2i2.6563

Nasihah, M., Istianah, I., \& Saraswati, A. A. (2019). Strategi Pengembangan Pola Hidup Bersih Dan Sehat (PHBS) dalam Mengantisipasi Penyakit Berbasis Lingkungan (PBL). Jurnal Abdimas Berdaya: Jurnal Pembelajaran, Pemberdayaan Dan Pengabdian Masyarakat. https://doi.org/10.30736/jab.v2i02.3

Purnama, T. B., Eliandy, S. R. H., \& Lestari, C. (2020). Perilaku Cuci Tangan Pakai Sabun pada Santri di Pondok Pesantren Kota Medan. Jurnal Promosi Kesehatan Indonesia, 15(2), 70-74. https://doi.org/10.14710/jpki.15.2.70-74

Syafe'i, I. (2017). Pondok Pesantren: Lembaga Pendidikan Pembentukan Karakter. Al-Tadzkiyyah: Jurnal Pendidikan Islam. https://doi.org/10.24042/atjpi.v8i1.2097

Wahyudin, U., \& Arifin, H. S. (2015). Sosialisasi Sanitasi Diri Dan Lingkungan Di Pesantren Salafi Melalui Pos Kesehatan Pesantren (Poskestren) Dalam Membentuk Sikap Santri Terhadap Sanitasi. Jurnal Kajian Komunikasi, 3(2), 148-153. https://doi.org/10.24198/jkk.v3i2.7405

Zakiudin, A., \& Shaluhiyah, Z. (2016). Perilaku Kebersihan Diri (Personal Hygiene) Santri di Pondok Pesantren Wilayah Kabupaten Brebes. Jurnal Promosi Kesehatan Indonesia, 11(2), 64-78. 
